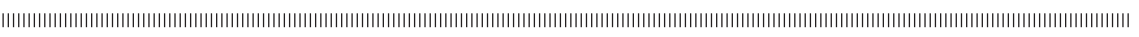

「革新的新構造材料等研究開発」プロジェクト（接合技術）特集：解説

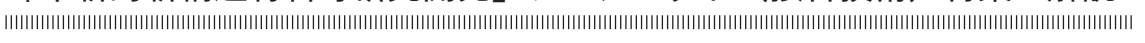

軽金属 第69巻第2号 (2019)，74-80

\title{
アルミニウムと異種材料の点接合技術
}

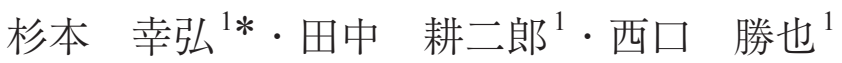

Journal of The Japan Institute of Light Metals, Vol. 69, No. 2 (2019), 74-80

(C) 2019 The Japan Institute of Light Metals

\section{Spot joining of aluminum and dissimilar materials}

\section{Yukihiro SUGIMOTO $^{1 *}$, Kojiro TANAKA $^{1}$ and Katsuya NISHIGUCHI ${ }^{1}$}

Keywords: body; weight reduction; multi-material; dissimilar joining; aluminum

\section{1.はじめに}

自動車や航空機などの輸送機器には温室効果ガスである $\mathrm{CO}_{2}$ の排出削減が求められており, 燃費改善に繋がる軽量化 はその有効な手段である。自動車においては車体の抜本的な 軽量化を狙いに，従来の鋼板製車体のような単一材料ではな く，各種構造材料の特長を生かした適材適所の材料配置（マ ルチマテリアル車体）の研究が進められている。

図 1 にマルチマテリアル車体構想の一例を示す ${ }^{1)}$ 。その実 現には材料の高性能化と低コスト化を両立するための研究開 発と, 異種材料からなる複数の部材を組み付けるための接合 技術が不可欠である。平成 26 年度から開始されたNEDO委 託事業「革新的新構造材料等研究開発」では, 中長期的な視 点で革新鋼板や革新アルミニウム, 炭素繊維強化プラスチッ ク（CFRP）などのマルチマテリアル化に資する軽量材料と それらの接合技術が開発されつつある。

本稿では，その研究テーマのひとつである「アルミニウム と異種材料の点接合技術」について, 研究開発の背景とこれ までの研究成果を紹介する。

\section{2. マルチマテリアル車体}

\section{1 車体の軽量化}

図2 は一般的な乗用車の重量構成である。ボディシェ ル（骨格）とクロージャー（蓋物）からなる車体は車両重量

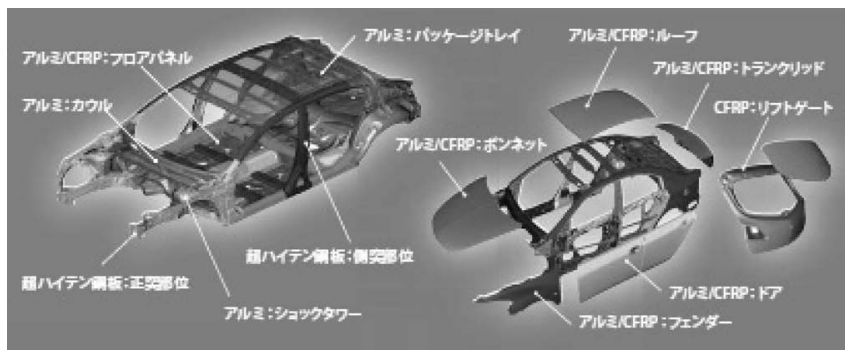

図1 マルチマテリアル車体構想の一例
の約 $40 \%$ を占め, その軽量化はシャシ等の軽量化にも波及 する。また, 車体は衝突安全や操縦安定性などの車両性能に 直結する重要な構造体であること, さらにその基本構造や生 産工程の変更は多大な設備投資を伴うことから，車体をどう 軽くするかが自動車メーカーの関心事であり, その構造最適 化と材料・工法の選択が車両重量低減の鍵を握る。

図3に車体軽量化のロードマップを示す。高張力鋼板（ハ イテン）やホットスタンプ材などの鋼板の使い切りを経て
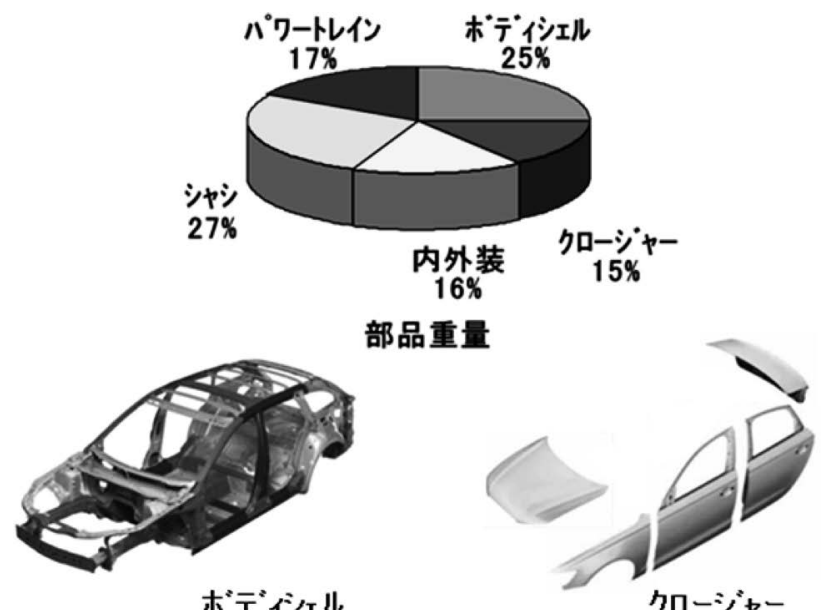

ボデジル クロージャー

図2 乗用車の重量構成

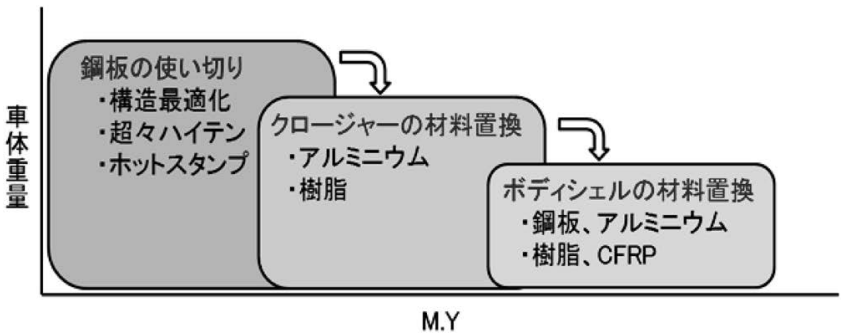

図3 車体軽量化のロードマップ

1 マッダ株式会社 技術研究所（† 739-8670 広島県安芸郡府中町新地 3-1） Technical Research Center, Mazda Motor Corporation (3-1 Shinchi, Fuchu-cho, Aki-gun, Hiroshima-shi, Hiroshima 739-8670)

* 責任著者E-mail: sugimoto.y@mazda.co.jp

受付日：2018年7月23日＼cjkstart受理日：2018年 8 月 22 日 
表 1 輸送機器の巡航速度と主要材料

\begin{tabular}{|c|c|c|c|}
\hline \multirow{2}{*}{ 輸送機器 } & \multirow{2}{*}{ 巡航速度（km/h） } & \multicolumn{2}{|c|}{ 主要材料 } \\
\hline & & 現状 & 将来予測 \\
\hline 航空機（B787） & 900 & $\mathrm{CFRP} /$ $/$ ミニウム／チタン & $\leftarrow$ \\
\hline 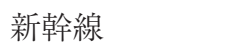 & 300 & アルミニウム & アルミニウム／マグネシウム \\
\hline 自動車 & 100 & 鋼板 & 鋼板 /アルミニウム / 樹脂 (CFRP含む) \\
\hline 大型タンカー & 30 & 鋼板 & $\leftarrow$ \\
\hline
\end{tabular}

中長期的にはマルチマテリアル化が進展するというのが現時 点での趨勢である。

高価格帯のプレミアム車が多い欧州においては，鋼板やア ルミニウム，CFRP等を組み合わせたマルチマテリアル車体 がすでに実用化されており，この技術分野では日本よりも 先行している。Audi Q7の車体は重量比率でアルミニウムが $52 \%$ ，鋼板が48\%であり，さらにBMW 7seriesではCFRPが 一部の構造部材に採用された ${ }^{2), 3)}$ 。

一方，日本国内では高品質の自動車用高張力鋼板が調達で きることもあり, マルチマテリアル化は緒に就いたばかりで あるが，生産台数の少ない一部の高級車やスポーツカーで実 用化が加速している。

\section{2 輸送機器の軽量化効果}

同じ輸送機器でも自動車と他の輸送機器の材料では満たす べき要件に自ずと違いがある。表 1 に輸送機器の巡航速度と 主要材料の現状と将来予測を示す。エネルギー消費う運動 エネルギー（質量 $\times$ 速度 ${ }^{2}$ ) と仮定すると, 時速 $900 \mathrm{~km} / \mathrm{h}$ の 航空機のエネルギー消費に及ぼす重量低減の効果は, 自動 車（時速 $100 \mathrm{~km} / \mathrm{h}$ ）の 81 倍である。

自動車は加減速を繰り返すため，実際にはこれほどの差は ないにしても，エネルギー消費に及ぼす重量低減の効果は航 空機に比べるとはるかに小さいものと考えられる。このこと は, $\mathrm{CO}_{2}$ 削減を目的とした自動車の軽量化には航空機ほどの コストが掛けられないことを示唆している。

さらに，地球規模での $\mathrm{CO}_{2}$ 排出削減という目的に対しては プレミアム車よりも生産台数の多い量販車の燃費改善が重要 であり，材料や工法に関わるコストが車体材料の重要な選定 指針になる。なお，新幹線並みの最高速度 $300 \mathrm{~km} / \mathrm{h}$ を超える スポーツカーなど，燃費性能ではなく運動性能の極限を目指 す自動車の軽量化はこの限りではない。

\section{3 構造材料の現状}

\subsection{1 機械的性質}

車体用の構造材料としては鋼板やアルミニウム, マグネシ ウム, 繊維強化プラスチック（FRP）などが候補に挙がる。 なかでもCFRPは航空機での使用が拡大していることもあ り，次世代自動車材料としても注目されている。

図4に各種構造材料の機械的性質を示す。図中には前述の NEDO委託事業における革新材料の開発目標值も併記した。 鋼板は引張強度で $270 \sim 1800 \mathrm{MPa}$ と材料選択の幅が広い。ま た，既存のアルミニウム展伸材は 70〜 $600 \mathrm{MPa}$ であり，強度 レベルが同じ場合には鋼板よりも伸びが小さい。革新材料の 開発目標を見ると，革新アルミニウムは既存ハイテン並みの 特性を，革新マグネシウムは既存アルミニウム並みの特性を 達成しょうとするものであり，機械的性質に限ると鋼板の優

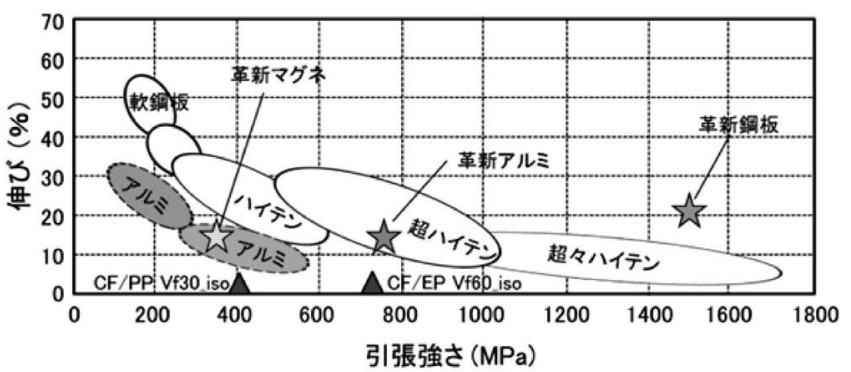

図4 各種構造材料の機械的性質

位性は将来にわたっても変わらない。

一方，パネル部材の剛性はヤング率と断面係数で決まる。 ヤング率が低い軽量材料では板厚を増やして鋼板並みの剛性 を得ることになるが，その場合でも比重が小さいため，部材 としての重量は軽くなる。鋼板パネル部材をアルミニウムで 置き換えると，板厚は 1.4 倍になるが，重量はほぼ半減する。 スポーツカーや高級車のボンネット等が鋼板からアルミニウ ムに置き換わりつつある理由である。

2.3.2 調達性, リサイクル

年間の世界生産台数が 8,000 万台を超える自動車の場合, 調達性やリサイクルも材料の選定指針となる。表 2 に全世界 での主要構造材の生産量と材料およびリサイクルのコスト差 を示す。

粗鋼の生産量 16 億トンに対し，アルミニウムが 5,000 万ト ン, マグネシウムが 100 万トン，炭素纎維が 6 万トンであり, 量販車への適用を想定した場合，マグネシウムや炭素繊維は 調達性に課題が残る。また，鋼板やアルミニウムのスクラッ プは有価物として売買されるのに対し，CFRPは現時点では 廃棄物として処理されることになる。アルミニウムは鋼板に 次いで生産量が多く, リサイクル市場も機能しており，材料 価格も含めて最も現実的な車体用軽量材料といえる。

なお，CFRPは優れた材料性能を有するものの，短中期的 には調達性や材料価格, リサイクルなどに課題があるため, 適材適所の原則に従い，その特長を最大限に発揮できる部 位（付加価值が大きい部位）に限定的に用いるのが妥当と考 えられる。

\section{4 量販車のマルチマテリアル化}

2. 4.1 車体構造, 材料

以上のような $\mathrm{CO}_{2}$ 排出削減に及ぼす自動車の軽量化効果や 各種構造材料の現状を考慮すると, 量販車のマルチマテリア ル車体は金属主体（鋼板やアルミニウム）のモノコック構造 で，これにクロージャーなどのパネル類を中心にアルミニウ ムや繊維強化プラスチックが適用される可能性が高い。一部 
表2 主要構造材の生産量と材料およびリサイクルのコスト差

\begin{tabular}{|c|c|c|c|}
\hline 材料 & 生産量（万トン） & $\begin{array}{c}\text { 材料価格比 } \\
\text { (めつき鋼板を 100) }\end{array}$ & $\begin{array}{c}\text { リサイクル } \\
\text { (スクラップ買取価格) }\end{array}$ \\
\hline 粗鋼 & $\begin{array}{c}162,040(2015) \\
\text { 世界鉄鋼協会統計 } 2016\end{array}$ & $\begin{array}{c}\text { 覀鉛めっき鋼板 } \\
(100)\end{array}$ & $\begin{array}{c}\bigcirc \\
(15 \text { 円 } / \mathrm{kg} \sim)\end{array}$ \\
\hline アルミニウム新地金 & $\begin{array}{c}5,004(2014) \\
\text { 経産省非鉄金属戦略2016 }\end{array}$ & $\begin{array}{c}\text { アルミニウム圧延板 } \\
(500)\end{array}$ & $\begin{array}{c}\bigcirc \\
(75 \text { 円 } / \mathrm{kg} \sim)\end{array}$ \\
\hline マグネシウム新地金 & $\begin{array}{c}102(2014 ） \\
\text { 経産省非鉄金属戦略2016 }\end{array}$ & $\begin{array}{c}\text { マグネシウム圧延板 } \\
(2000)\end{array}$ & $\begin{array}{c}\times \\
\text { 市場なし }\end{array}$ \\
\hline 炭素繊維 & $\begin{array}{c}6(2015) \\
\text { 三菱レイヨン技術資料 }\end{array}$ & $\begin{array}{c}\text { PP-CF40ペレット } \\
(3000)\end{array}$ & $\begin{array}{c}\times \\
\text { サーマル, 埋立 }\end{array}$ \\
\hline
\end{tabular}

（材料価格比およびスクラップ買取価格は参考值）

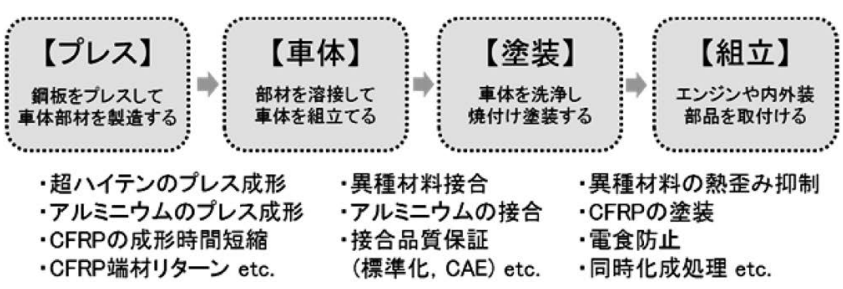

図5 マルチマテリアル車体の主要課題

のスポーツカーでは，車体骨格をアルミニウム押出形材で構 成するスペースフレーム構造が採用されているが, 生産方式 や生産タクトの点で量販車には不向きである。

なお，マルチマテリアル車体では鋼板よりも高価な材料の 使用比率が増加する。量販車への展開にあたっては, この材 料費の低減に加え, 設備投資抑制やグローバル生産対応の観 点から既存の車体製造ラインを活用した生産が不可欠になる ものと考えられる。

\section{4.2 生産上の課題}

図 5 に既存の車体製造ラインを活用してマルチマテリアル 車体を生産する場合の主要課題を示す。アルミニウムのプレ ス成形性は鋼板よりも劣るため, 部材によっては形状の見直 しや分割が必要になる。プレス成形のサイクルタイムは数秒 程度であるのに対し，CFRPの成形には最新技術を用いても 3〜10分程度を要する。

また，鋼板車体の接合には抵抗スポット溶接が 1 台あたり 3,000 4,000 点程度使用されているが, マルチマテリアル化 にあたっては異種材料からなる複数の部材を組付けるための 接合技術も不可欠である。

これら CFRPの成形時間短縮や異種材料接合はNEDO委託 事業の主要課題でもある。以下に異種材料接合技術の現状と 委託事業の研究テーマである「アルミニウムと異種材料の点 接合技術」の概要を報告する。

\section{3. 異種材料接合の現状}

\section{1 機械的接合}

欧州のマルチマテリアル車体ではリベットやスクリュー等 を用いた機械的接合が採用されている。例えば前述のAudi Q7では, アルミニウム同士の接合やアルミニウムと鋼板の 異種材料接合にはセルフピアシングリベット（SPR）が約
2,600点, フロードリルスクリュー（FDS）が600点, アルミ ニウムと超ハイテン（1000 MPa超級）の接合にはスペシャ ルセルフピアシングリベット（SSR）が230点, フリクショ ンエレメントウェルディング（FEW）が100点程度用いられ

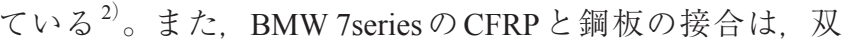
方の部材に下穴を開け，それをブラインドリベットで締結し ている。

\section{2 直接接合}

一方，日本ではリベット等を用いずに異種材料を直接接合 する研究が従来から活発に行われてきた。表了にNEDO委託 事業で開発中の技術も含め, 異種材料接合の研究例を示す。 アークやレーザを用いた溶接やろう付け，摩擦擋拌接合，超 音波接合など多岐に及ぶ。なかでも摩擦擋拌接合は，母材に 対して回転ツールによる摩擦熱と圧力を同時に加えられるこ とや塑性流動により金属表面の酸化物や吸着ガス等の不純物 が除去できること，さらに固相接合のため脆弱な金属間化合 物の生成が抑制されるといった特長があり，異種材料接合へ の応用研究と実用化が進んでいる。

例えば摩擦摚拌点接合を用いた異種材料接合はアルミニ ウム製トランクリッドと鋼板製補強材との接合に適用され た ${ }^{4 ｝ \text { 。実用化にあたってはアルミニウムの相手材として亜 }$ 鉛めっき鋼板が用いられた。亜鉛めっきの融点はおおむね $400^{\circ} \mathrm{C}$ 程度であり, 接合時の摩擦熱により亜鉛めっきが溶融 し，接合界面から排出される。その結果，下地である鋼板の 新生面が露出, その新生面とアルミニウムが固相接合され る。

また，摩擦擋拌連続接合は自動車のフロントサブフレーム のアルミニウムダイカストと鋼板（合金化溶融亚鉛めっき） との異種材料接合で実用化された ${ }^{5)}$ 。この実用例の特徵はア ルミニウムダイカスト側から挿入された回転ツールの先端が 鋼板表面を削るように制御されていることである。これによ り鋼板の新生面が露出し, アルミニウムと接合される。アル ミニウムと鋼板の連続接合では重ね合わせだけでなく，突合 せ継手についても研究が進んでいる。この場合も鋼板側の新 生面を得るために回転ツールの軌跡を鋼板側にオフセットさ せ，鋼板端面を削ることで接合強度が向上することが知られ ている6)。

なお，NEDO委託事業では，この摩擦摚拌接合に加え， レーザや抵抗スポット溶接による異種材料接合の研究が行わ 
表 3 異種材料接合の研究例

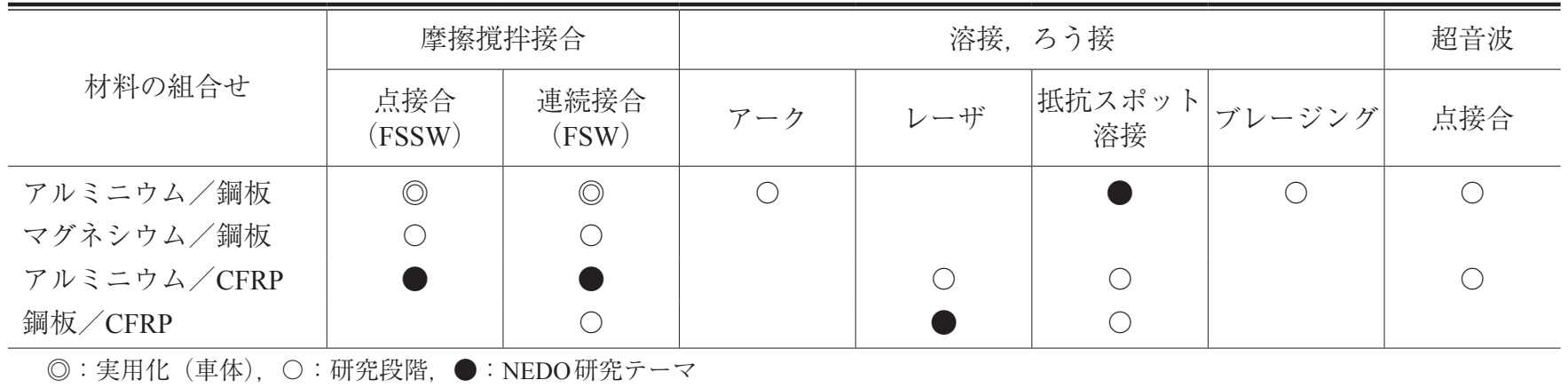

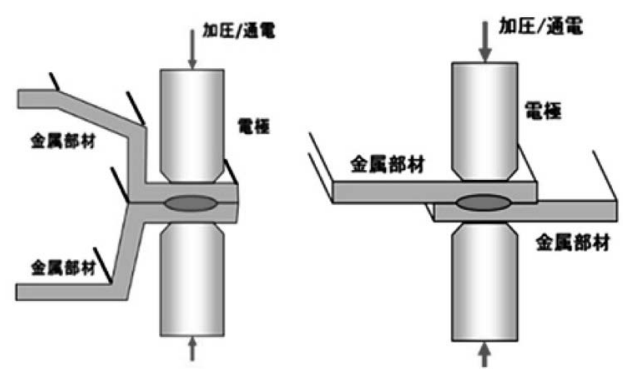

車体接合技術の要件

・ローコスト(リベット等の変動費削減)

・ロバスト性(板間隙、ブレス油付着eto)

・ロボットによる施工

・抵抗スポット溶接並みのサイクルタイム ・板組( 材質、総板厚)に対する自由度

図6 抵抗スポット溶接と車体接合技術の要件

れて抢り、アルミニウムと鋼板，さらには金属とCFRPとの 直接接合が可能になりつつある。

\section{4. アルミニウム / 異種材料の点接合技術の開発}

\section{1 車体接合の要件}

以上のように種々の材料組合せを想定した異種材料接合技 術が開発されつつあり，マルチマテリアル車体の接合技術の 選択肢は拡大している。一方，鋼板車体に多用されている抵 抗スポット溶接は，図6に示すように部材のフランジ同士を 重ねて一対の電極で挟み，大電流によるジュール熱で溶融ナ ゲットを形成する接合法であり，車体接合技術としての優れ た特長を備えている。

鋼板車体には軟鋼板から超ハイテンまでの種々の材料が用 いられ，それらの板厚も多岐に及ぶ。抵抗スポット溶接では 母材の材質や板厚に応じて通電条件を変更するだけでよく, 板組に対する自由度が大きい。図6には車体接合技術が具備 すべき要件も併せて示している。マルチマテリアル車体に適 用される異種材料接合にも抵抗スポット溶接並みの品質やコ ス卜，生産性が望まれる。

\section{2 技術開発コンセプト}

量販車を想定したマルチマテリアル車体は，前述のように 鋼板やアルミニウムなどの金属が主体で, CFRPはその特長 を最大限に発揮できる部位に限定的に用いられる可能性が高 い。したがって，それら部材の組付けには鋼板・アルミニウ ム・CFRPを相互に接合できる異種材料接合技術が必要とな

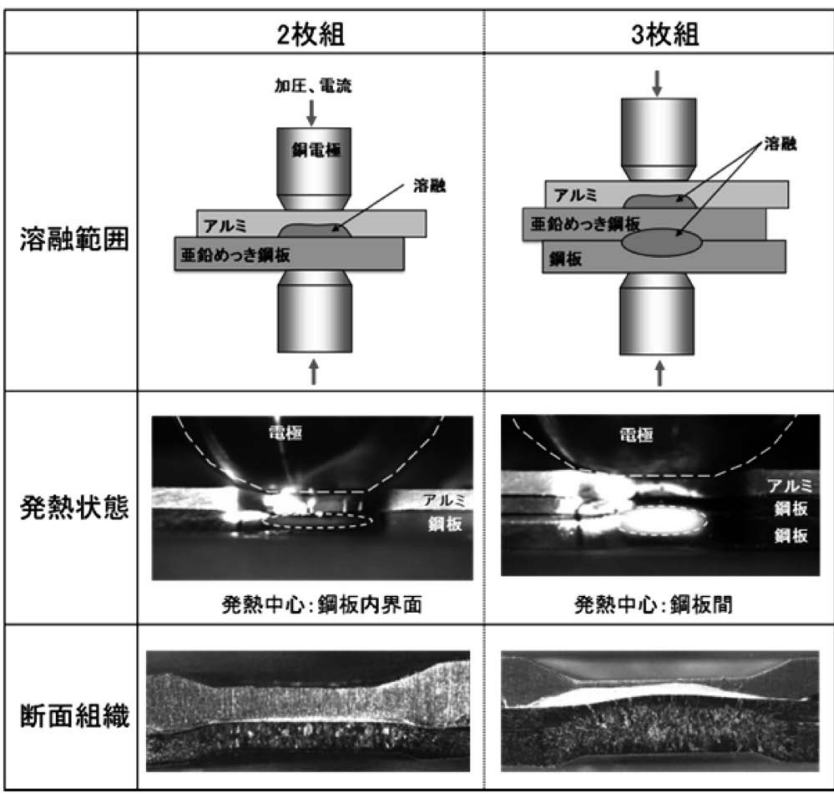

図7アルミニウム／鋼板の抵抗スポット溶接

る。

そこで，NEDO委託事業では，「既存の車体製造ラインへ の適合性が高く、リベットやスクリューなどの副資材を必要 としないローコストの直接接合」を開発コンセプトとして, 異種材料接合技術の開発に取り組んだ。

具体的には, アルミニウム /鋼板 /鋼板の3枚組の接合に も対応できる抵抗スポット溶接 ${ }^{7}$ と, アルミニウム / CFRP の摩擦摚拌点接合 ${ }^{8), 9)}$ である。以下にそれぞれの技術概要 を紹介する。

\section{3 アルミニウム/鋼板の抵抗スポット溶接}

4.3.1 接合原理

アルミニウムと鋼板の異種材料接合では，接合界面にお ける脆弱な $\mathrm{Al}-\mathrm{Fe}$ 系金属間化合物の形成を抑制する必要があ る。そこで, 直流インバー夕方式の抵抗溶接機を用い, 図7 に示すようにアルミニウムと鋼板の接合界面ではアルミニウ ムのみが溶融するように通電制御する。アルミニウム/鋼 板／鋼板の 3 枚組の場合には最初に中板と下板の鋼板界面が 発熱して溶融ナゲットが形成され，その熱が中板を介して上 板に伝わり，アルミニウムのみが溶融する。

アルミニウム表面の酸化膜はアルミニウムが溶融すること で破壊されるが，それに接する鋼板は固相のままであり，そ の表面酸化物が接合性を阻害する。そこで, アルミニウム／ 


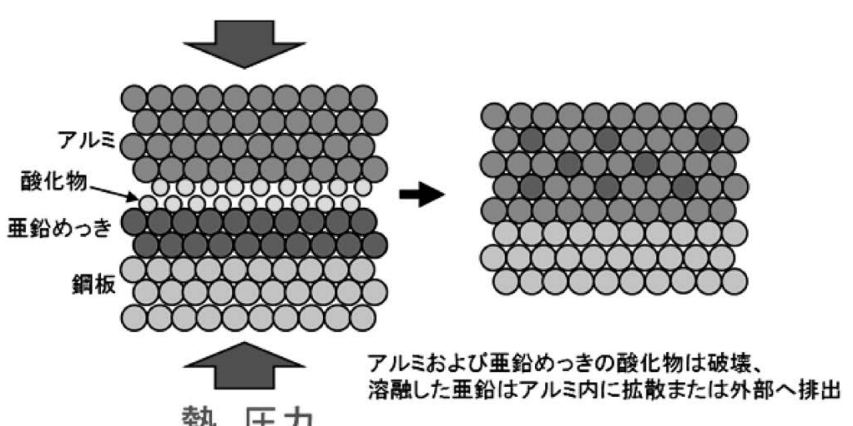

熱、圧力

図8 亜鉛めっきの役割

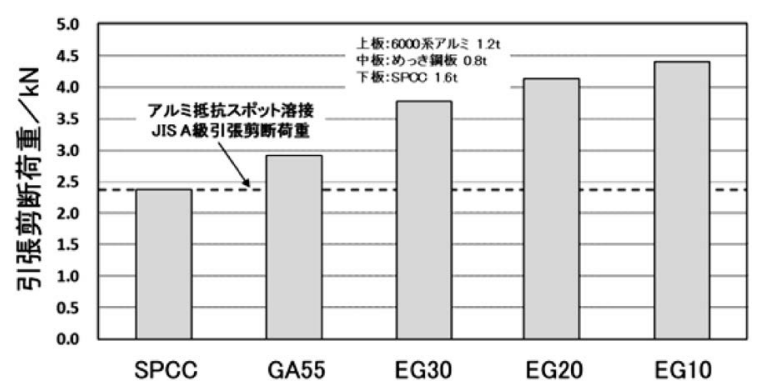

図 9 鋼板表面処理と引張剪断荷重

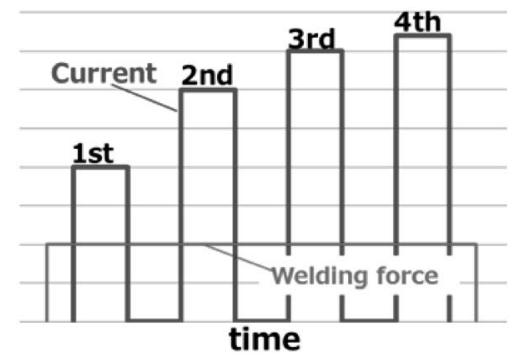

図10 通電パターン

鋼板の摩擦摚拌点接合と同様, アルミニウムと接する鋼板に は亜鉛めっき材を用い, 酸化物等の悪影響を回避している。 図8に亜鉛めっきの役割を示す。溶接中に亜鉛めっきが溶融 し, 接合界面から排出され, 下地である鋼板の新生面が露出, その新生面とアルミニウムが接合される。

\section{3.2 通電条件の検討}

3枚組の中板（アルミニウムに接する鋼板）の表面処理と 引張剪断荷重の関係を図9に示す。非めっき鋼板（SPCC） に比べ，合金化溶融亜鉛めっき鋼板 $(\mathrm{GA})$ や電気亜鉛めっ き鋼板（EG）を用いることで引張剪断荷重が向上する。GA よりも EGの方が高い值を示す。これはめっきの融点が低く かつ薄目付ほど，接合界面からのめっき成分の排出が容易な ためであるが，逆にめっき成分の排出が不十分な場合には強 度低下の要因になることを示唆している。

そこで国内の自動車用防錆鋼板としては主流の厚目付 GA 材でも高い接合強度が得られるよう通電条件を検討した。そ の結果，通電の多段化が接合界面からのめっき成分の排出に 有効であることがわかった。図 10 に通電パターンを, 図11 に十字引張試験結果に示す。冷却時間を挟んで段階的に溶接 電流を高めることで，GA材の場合でも高い接合強度が得ら れた。図12には超ハイテン材を含む板組での引張剪断荷重 を示す。アルミニウム $/ 980 \mathrm{MPa}$ 級 GAハイテンの2 枚組や

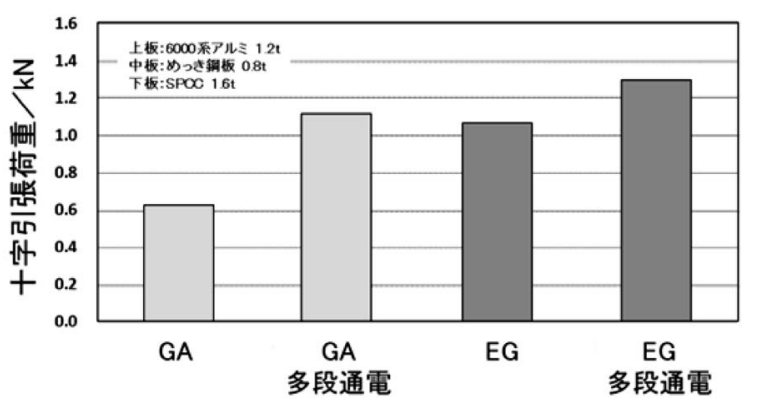

図11 十字引張試験結果

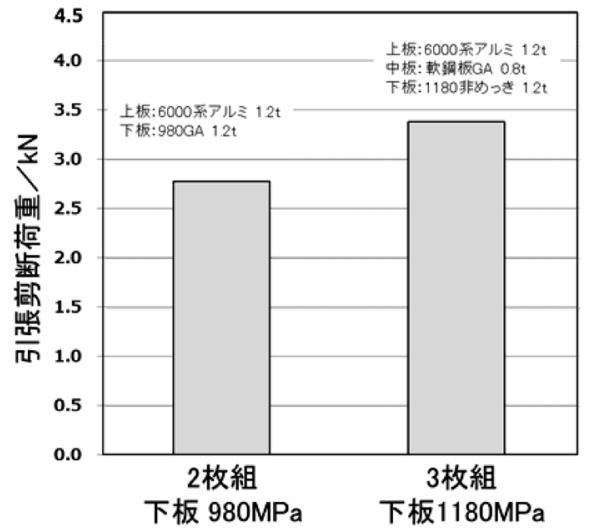

図12＼cjkstart超ハイテン材を含む板組での引張剪断荷重

アルミニウム $/ \mathrm{GA}$ 軟鋼板 $/ 1180 \mathrm{MPa}$ 級ハイテンの3枚組で もアルミニウム抵抗スポット溶接 JIS A 級引張剪断荷重を超 える強度が得られており, いずれもアルミニウムのボタン破 断を呈した。

本技術は鋼板車体と同じプロセスである抵抗スポット溶接 であり，鋼板車体とマルチマテリアル車体の設備を共用する ことで，それらの混流生産にも対応できる可能性がある。リ ベット等の副資材も不要で, 鋼板のめっき種や強度グレード の制約も受けにくいことから，アルミニウムと鋼板のローコ ストな異種材料接合法として有望と考えられる。

\section{4 アルミニウム/CFRPの摩擦擋䢁点接合}

4. 4.1 接合原理

アルミニウム同士の摩擦擋汼点接合では, 図13に示すよ うに3,000 rpm 程度で回転する鋼製ツールの突起部（プロー ブ）が下板まで挿入され，摩擦熱で軟化したアルミニウムが 塑性流動し，下板が上板に楔状に入り込んで固相状態で接合 される。一方，アルミニウム／鋼板の接合ではツールは上板 のアルミニウムに留まるように制御され，摩擦熱とツールの 押圧により下板の鋼板の亜鉛めっきが溶融排出され, 下地の 鋼板新生面にアルミニウムが溶着される。

アルミニウム $/ \mathrm{CFRP} の$ 異種材料点接合は後者の形態に近 い。すなわち, ツールはアルミニウム内部で留まり，摩擦熱 で融けた樹脂がアルミニウムに溶着する。ポリアミドなどの 熱可塑性樹脂やそれらをマトリックスとする繊維強化プラス チックが接合できる。

その接合メカニズムを明らかにするため接合界面を電子顕 微鏡で観察した。結果を図14に示す。アルミニウムの薄い 酸化膜を介して樹脂が溶着していることがわかる。熱可塑性 樹脂でも官能基を持たないポリプロピレンとは十分な接合強 


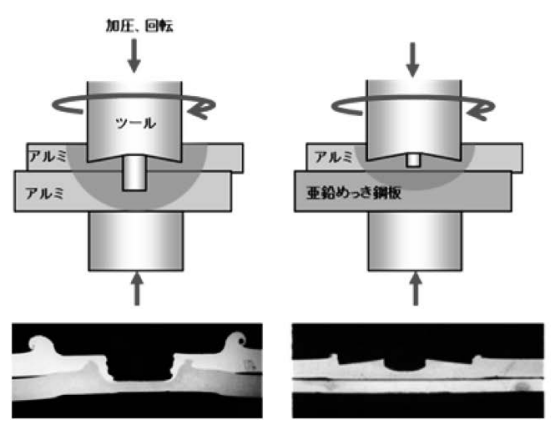

図13 摩擦摚汼点接合
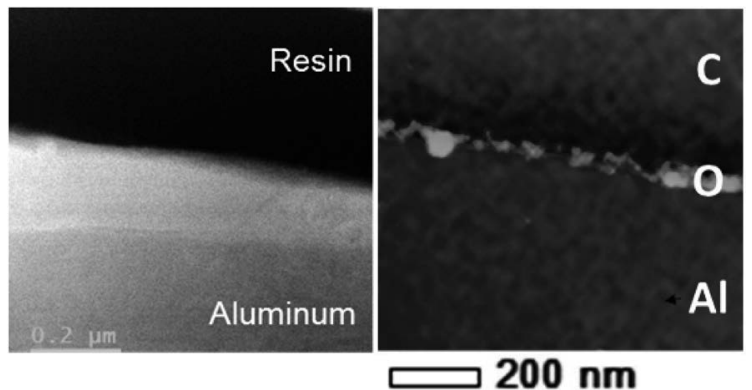

HAADF像

元素マッピング

図 14 電子顕微鏡による接合断面観察

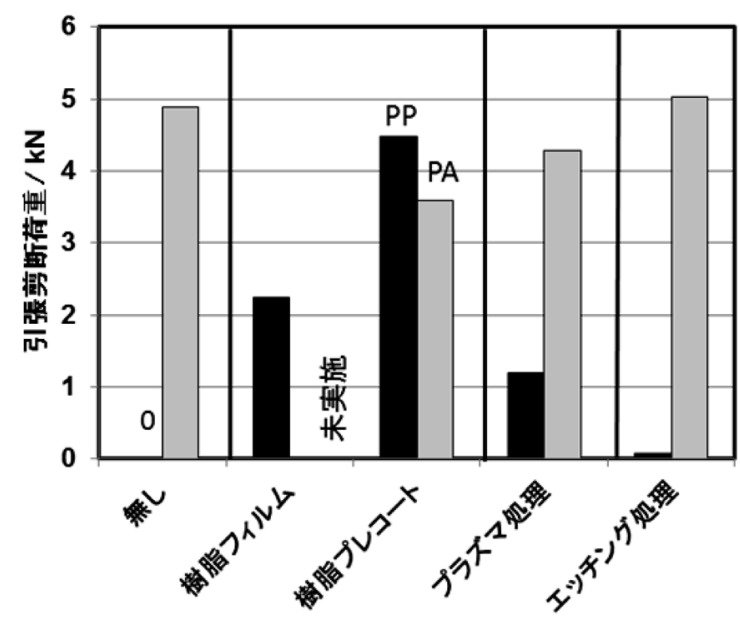

図 15 表面処理による接合性改善

度が得られないことから，極性を有する樹脂官能基と酸化ア ルミニウムとの分子間力に起因した結合と考えられる。事 実，ポリプロピレンに官能基（- $\mathrm{COOH}$ な゙）を添加するこ とで，アミド基を有するポリアミドと同様に接合できること がわかっている。また，図15に示すように，接合相手材が ポリプロピレンの場合には，樹脂への官能基添加だけでな く，アルミニウム側にポリプロピレンと相溶性のある樹脂 コーティング等を施すことでも接合性が向上する。

\section{4.2 接合強度}

アルミニウム / CFRP摩擦擋汼点接合の引張剪断荷重を ISO19095に準じて計測した。アルミニウムには酸洗浄した JIS A5182（幅 $30 \mathrm{~mm} \times$ 板厚 $1.2 \mathrm{~mm}$ ），CFRPには非連続炭素 繊維を $40 \%$ 含有したポリプロピレン射出成形材（幅 $30 \mathrm{~mm}$ ×板厚 $3 \mathrm{~mm}$ ）を用い，30 $\mathrm{mm}$ の重ね代の中央部をアルミニウ ム側から点接合した。接合には位置制御型の摩擦擋拌点接

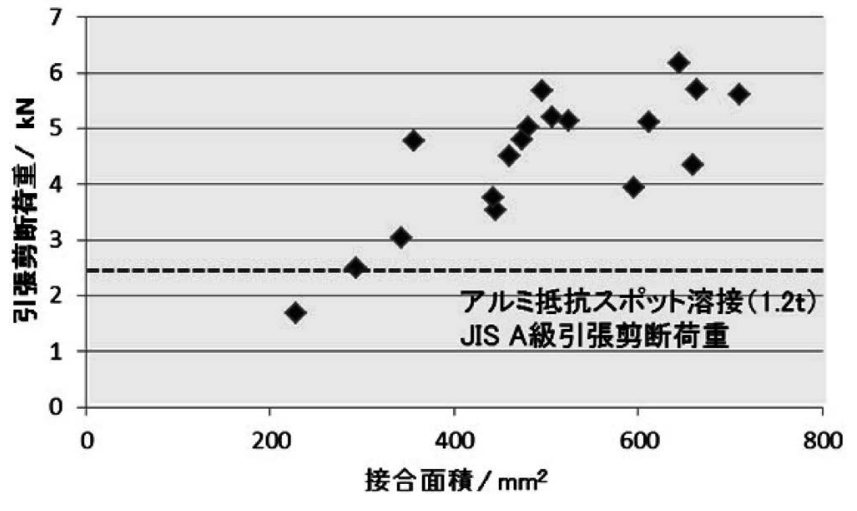

図 16 引張剪断試験結果
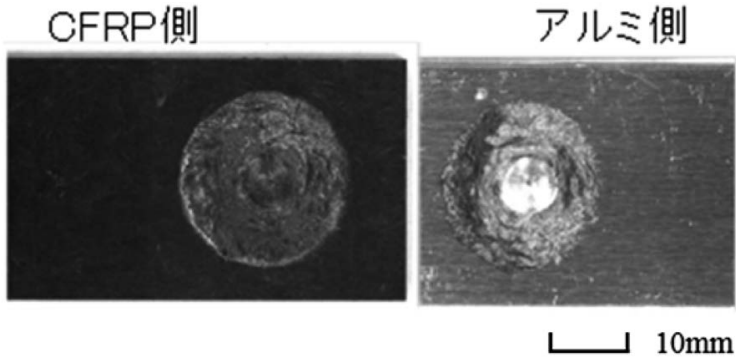

図17 試験後の剥離面

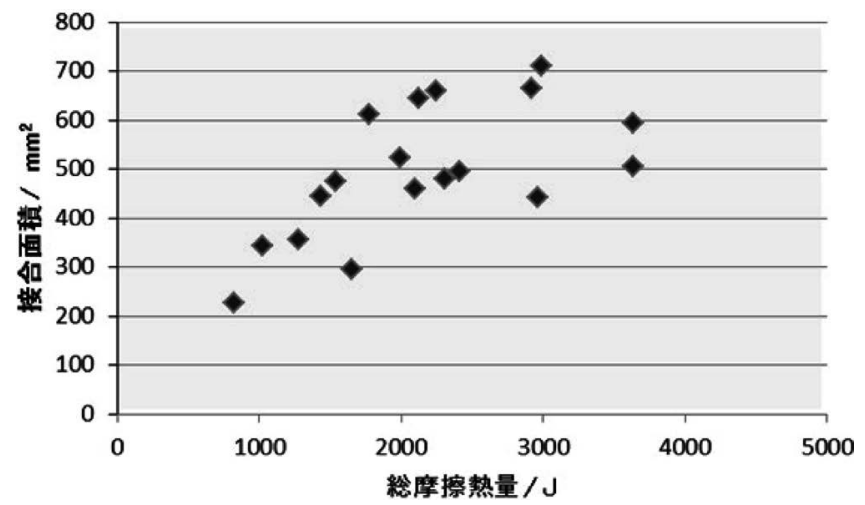

図 18 総摩擦熱量と接合面積

合装置を用い, ツール挿入深さを $1 \mathrm{~mm}$ とした。また, ツー ル径と挿入速度，回転数等を適宜選択し，接合面積が200 $800 \mathrm{~mm}^{2}$ の範囲の試験片を作成した。

図16に試験結果を示す。引張剪断荷重はおおむね接合面 積に比例している。板厚 $1.2 \mathrm{~mm}$ のアルミニウム抵抗スポッ 卜溶接JIS A 級引張剪断荷重を超える值を示しており, 強度 部材の接合に必要な強度基準を満たすレベルにある。試験後 の剥離面を図17に示す。摩擦熱によりツール径の2 倍程度 の範囲の樹脂表層部が溶融し，アルミニウムに溶着してい る。アルミニウム側には部分的に樹脂成分や炭素繊維が付着 しており，樹脂の凝集破壊の傾向が見られた。

なお，摩擦熱は，その一部がッールにも伝達されるため必 ずしも接合部に投入された正味の熱量ではないが，品質とプ ロセスパラメータを関連づける有効な管理指標である。そこ で，接合中のツール駆動用サーボモーターのトルク変動を もとに単位時間あたりの摩擦熱 $(\mathrm{J} / \mathrm{s})=$ トルク $(\mathrm{Nm}) \times$ 回転 数 $(\mathrm{rpm}) \times 0.1047$ を求め, 最大摩擦熱（摩擦熱の最大值）と 
総摩擦熱量（摩擦熱を時間で積分した值）を定義した。

図 18 に総摩擦熱量と接合面積の関係を示す。両者には相 関があり，要求強度レベルやマトリックス樹脂の熱的性質に 応じてプロセスパラメー夕を設定することで多様な CFRPの 接合が可能と考えられる。

\section{5. まと め}

構造材料のコストや調達性, リサイクル等を考慮すると, 量販車を想定したマルチマテリアル車体は金属主体（鋼板, アルミニウム）で，これにクロージャーなどのパネル類を中 心にアルミニウムや繊維強化プラスチックが適用される可能 性が高い。

NEDO 委託事業では，既存の車体製造ラインへの適合性が 高く, リベットなどの副資材を必要としないローコストな直 接接合法として，アルミニウム／鋼板の抵抗スポット溶接 とアルミニウム / CFRPの摩擦摚找点接合の開発に取り組ん だ。

その結果，いずれの接合法でもアルミニウム抵抗スポット 溶接の JIS A 級引張剪断荷重を上回る值が得られており, 特 に強さを要する接合部にも適用可能なレベルに達した。

今後は車体組立工程の外乱に対するロバスト性の確保や市
場環境を想定した耐久信頼性の検証, 品質保証方法の検討を 進める。

\section{謝 辞}

アルミニウム／異種材料の点接合技術の成果は, 国立研究 開発法人新エネルギー・産業技術総合開発機構（NEDO）の 委託業務の結果得られたものです。

\section{参 考 文 献}

1) 新構造材料技術研究組合 REPORT, No. 1,(2015).

2) T. Hambrecht and U. Alber: AUDI AG, The new AUDI Q7, Presentation ECB 2015,(2015).

3) The new BMW 7 Series, EuroCarBody2015,(2015).

4) 玄道俊行, 西口勝也, 麻川元康：日本金属学会誌, 70 (2006), 870-873.

5) 畑 恒久, 矢羽々隆憲, 朝見明彦: 溶接学会全国大会講演概要 集, Vol. 2013f (2013). https://doi.org/10.14920/jwstaikai.2013f.0. 40.0

6) 福本昌宏, 椿 正巳, 下田陽一朗, 安井利明: 溶接学会論文集, 22 (2004), 309-314.

7) 田中耕二郎：軽金属溶接， 55-11 (2017)， 15-19.

8) 杉本幸弘, 田中耕二郎, 西口勝也 : 溶接学会平成 29 年度春季 全国大会フォーラム予稿集，(2017）。

9）杉本幸弘：溶接学会誌, 87 (2018)， 66-70. 